\title{
Mass mortality of herring eggs on spawning beds on and near Fisherman's Bank, Gulf of St. Lawrence, Canada
}

\author{
Shoukry. N. Messieh ${ }^{(1)}$ and Harald Rosenthal ${ }^{(2 *)}$ \\ (1) Department of Fisheries and Oceans, Bedford Institute of Oceanography, PO Box 1oo6, Dartmouth, Nova Scotia B2 $Y_{4} A 2$, Canada. \\ (2) National Research Council, Atlantic Research Laboratory, I44I Oxford Street, Halifax, Nova Scotia $B_{3} \mathrm{H}_{3} Z_{1}$, Canada.
}

Received August I 1, 1988, accepted February 10, 1989.

Messieh S. N., H. Rosenthal. Aquat. Living Resour., 1989, 2, 1-8.

Abstract

During a SCUBA survey on herring spawning beds on and near Fisherman's Bank (NAFO Div. 4T) conducted in September 1985, divers observed a spawning bed with heavy egg depositions, which frequently reached thicknesses between 20 to 30 layers. Continuous egg carpets of this thickness extended over an area of approximately $200 \times 500 \mathrm{~m}$. Most of the egg mass on this spawning bed was in a state of deterioration, showing mass mortality and extended fungi coverage.

Egg samples taken from various layers showed that almost all eggs were fertilized. Live egg batches were incubated for further observation. Embryos were found to be in various developmental stages. The rate of development was obviously related to the position within the egg mass. Many embryos from the surface appeared to be normal. All eggs located below the second layer exhibited embryos with various malformations.

Egg samples did not show any evidence of the presence of Ichtyophonus, a known fungal disease in herring. None of the isolates obtained are known to be pathogenic to fish eggs. The observed mass mortality of herring eggs on the spawning bed was mainly caused by spontaneous intensive mass spawning leading to an unusually dense packing of the deposited eggs and therefore not permitting sufficient separation for water exchange and oxygen supply.

Environmental factors accompanying such spontaneous mass spawning are not well understood. Vertical temperature profiles from nearby locations showed sudden sub-surface temperature changes coinciding with the time of spawning. Meteorological conditions indicated wind-related water displacement near the spawning bed. While no drastic change in temperature was observed near the surface, changes of about $8^{\circ} \mathrm{C}$ occurred in one day, at $20 \mathrm{~m}$ depth. These events may have triggered the mass spawning in a restricted area, later resulting in heavy mortalities when embryos reached advanced developmental stages requiring substantial oxygen supplies.

Keywords : Herring eggs, mortality, spawning beds, Gulf of St. Lawrence, Canada.

Mortalité en masse d'aufs de hareng sur les zones de reproduction, proches et sur le banc de Fisherman, dans le golfe du Saint-Laurent, Canada.

Résumé

Durant une campagne d'investigation SCUBA sur les zones de reproduction de hareng du banc de Fisherman et dans ses alentours (NAFO Div. 4 T), conduite en septembre 1985, des plongeurs ont observé une zone de ponte avec d'importants dépôts d'œufs, qui fréquemment, atteignent des épaisseurs de 20 à 30 couches. Ce tapis continu d'œufs s'étendait sur une surface de $200 \times 500 \mathrm{~m}$ environ. La

(*) Home address: Biologische Anstalt Helgoland, Zentrale Hamburg, Notkestrasse 31, 2000 Hamburg 52, Federal Republic of Germany. 
plupart de ces masses d'œufs se trouvaient en mauvaises conditions, donnant des signes de mortalité importante et couvertes de champignons.

Des prélèvements d'œufs pris dans différentes couches montrèrent que presque tous les œufs étaient fécondés. Des lots d'œu「s vivants furent mis en incubation pour des observations ultérieures. Différents stades de développement d'embryons ont été trouvés. Le niveau de développement était lié évidemment à l'emplacement dans la masse d'oufs. De nombreux embryons de la surface apparaissaient normaux. Tous les œufs situés sous la seconde couche comportaient diverses malformations.

La présence de Ichthyophonus, champignon connu du hareng, n'a pas été mise en évidence dans les prélèvements d'œufs. La mortalité importante observée sur ces œufs de hareng est due principalement à la ponte massive et intensive avec une accumulation inhabituelle de dépôts d'œufs ne permettant pas une séparation suffisante pour les échanges d'eau et les apports d'oxygène.

Les facteurs environnementaux accompagnant de telles pontes massives ne sont pas bien compris. Les profils verticaux de température montrèrent des changements soudains de température de surface lors de la période de reproduction. Des conditions météorologiques indiquèrent une relation avec la direction du vent près de la zone de ponte. Aucune variation de température n'a été observée près de la surface, à $20 \mathrm{~m}$ une variation de $8^{\prime \prime} \mathrm{C}$ a été signalée. Ces événements peuvent avoir déclenché la ponte massive sur une surface restreinte, ayant pour résultat de lourdes mortalités dès que les embryons atteignirent des stades avancés de développement qui nécessitent des apports substantiels d'oxygène.

Mots-clés : (Eufs de hareng, mortalité, zones de ponte, golfe du Saint-Laurent, Canada.

\section{INTRODUCTION}

The Gulf of St. Lawrence supports commercial fisheries for spring and fall spawning herring (Clupea harengus L.) populations (fig. 1). The spawning beds of spring herring are in shallower waters $(0.8-3.5 \mathrm{~m}$ at mean low water) and near shore. The spawning beds of fall herring are in deeper waters $(15-30 \mathrm{~m}$ MLW) and further offshore. The surveys of the spring spawning beds were carried out in Miramichi Bay in spring 1981, 1983 and 1984. Results of these surveys were reported by Messich et al. (1985a, 1985b).

In August 1985, a survey of spawning fall herring was carried out in Fisherman's Bank ( fig. 1) to delineate the spawning beds, to examine the egg density, and to estimate the spawning biomass. The Fisherman's Bank area was chosen because in recent years the herring fishery there was the largest in the Gulf of St. Lawrence and contributed to about half of the catch. This was the first time since 1962 that an in situ spawning bed survey was carried out using SCUBA diving techniques to study egg deposition by fall spawners along the east coast of Canada. Earlier studies concentrated on spring spawners. Tibbo et al. (1963) used free diving techniques to survey a spawning bed of spring herring near Blanchard Point, Chaleur Bay, New Brunswick, in May 1962, extending over an area of about $375000 \mathrm{~m}^{2}$. A single herring spawning bed was located during a May 1980 SCUBA survey of the spring spawning area in Miramachi Bay, New Brunswick, covering an area of approximately $113000 \mathrm{~m}^{2}$ (Pottle et al., 1980). Along the west coast of Canada, the escapement of herring spawners from the extended roe fishery is determined by estimating the density (intensity) and extent (total cumulative mileage) of egg deposition on the spawning grounds (Hourston et al., 1972; Hourston and Haegele, 1980), and sampling programs using SCUBA divers were employed for quite some time (Haegele et al., 1979, 1981; Humphreys and Haegele, 1976). A mode for predicting Pacific herring spawn density from diver observations was described by Schweigert and Fournier (1982). Other surveys carried out in Nova Scotian waters and on Georges Bank used grab samplers (McKenzie, 1964) and submersibles (northwest Atlantic) (Caddy and Iles, 1973; Noskov and Zinkevich, 1967).

The Fisherman's Bank spawning bed survey provided data that were used to estimate the spawning biomass (Messieh, 1987). During the survey, the divers discovered mass mortalities of herring eggs. Samples of dead eggs were collected for examination. Live eggs were incubated under controlled conditions, using a largely standardized bioassay technique. The present report summarizes the results of these studies.

\section{MATERIALS AND METHODS}

The search for herring spawning beds was conducted on Fisherman's Bank (N46 $01^{\prime} 00^{\prime \prime}$; W62 $\left.16^{\prime} 00^{\prime \prime}\right)$, located southeast of Prince Edward Island, Canada ( $f \mathrm{ig} .1$ ). The Bank covers an area of approximately $6 \mathrm{~km}^{2}$. Four SCUBA divers conducted the survey using a small $42 \mathrm{ft}$ fishing boat as a diving platform. Searches for herring by divers covered the entire area of the Bank from the end of August until the end of September, 1985.

Monitoring the commercial fishing activity on the Bank helped in locating the spawning beds. Herring are caught by drift-nets during their spawning migration. After locating the spawning bed, divers determined the boundaries. A buoy was placed at the last location in which eggs were found. 


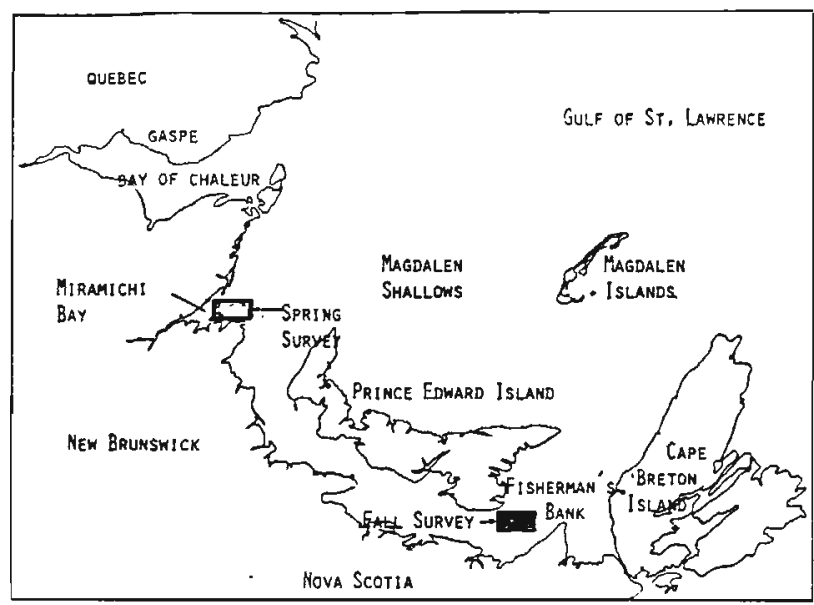

Figure 1. - Map of the Gulf of St. Lawrence showing the location of herring spawning bed surveys.

A sampling grid with $200 \mathrm{~m}$ intervals between stations was superimposed over the spawning bed. The locations of the stations were determined by LORAN $C$ navigation system, with an optimum accuracy (i.e. ability to return to the same position) of $\pm 15 \mathrm{~m}$.

Quadrat sampling began on September 6. At each station, divers collected all eggs within a randomly selected square of $0.25 \mathrm{~m}^{2}$. All loose material scraped from the substrate was propelled into collecting bags, using an airlift. In cases of heavy egg deposition, samples were not airlifted but cut out from the egg carpet within the quadrat. Samples of dead eggs were preserved for examination of their developmental status. Samples of live eggs were collected for bioassay incubation at the Fisheries Research Unit, University of PEI (Prince Edward Island). A circular tank attached to a recirculating seawater system (environmental conditions $12.5^{\circ} \mathrm{C}, 22-24 \mathrm{~S}^{\circ} \%, \mathrm{pH} \mathrm{7.0)} \mathrm{was} \mathrm{used}$ as an incubator. Egg clusters of various thicknesses were allowed to settle at the tank bottom and were exposed to a circular current of approximately $0.5 \mathrm{~cm} . \mathrm{s}^{-1}$ allowing sufficient water exchange in layers near the surface. Egg samples were taken at irregular intervals and cross-sections were examined for identification of developmental stages and malformations in the various layers. Temperature data were collected during the field survey. Continuous temperature recordings were taken at nearby stations using Ryan's thermographs. Meteorological data were obtained from Environment Canada for the two closest stations in Charlottetown and Magdalen Islands.

Egg samples were examined for pathogenic infections at the Fish Health Service Unit Laboratory, DFO, Halifax, Nova Scotia. Culture media included tryptic soy agar (with and without $\mathrm{NaCl}$ supplement of $2 \%$ ) for bacteria; HS agar for Myxobacteria, and Sabouraud's agar with penicillin-streptomycin (with and without $\mathrm{NaCl}$ supplement) for fungi. Egg extracts were assayed for the presence of fish viruses using guppy tissue culture cell monolayers.

\section{RESULTS}

\section{Location and condition of the spawning beds}

The substrate of Fisherman's Bank consists mostly of bedrock mixed with pebble; algal cover is negligible. The depth of the Bank ranges from $10 \mathrm{~m}$ to $25 \mathrm{~m}$. Two of the spawning beds were found in 10 to $15 \mathrm{~m}$ depth. The other 3 spawning beds were located at a depth of $20-25 \mathrm{~m}$.

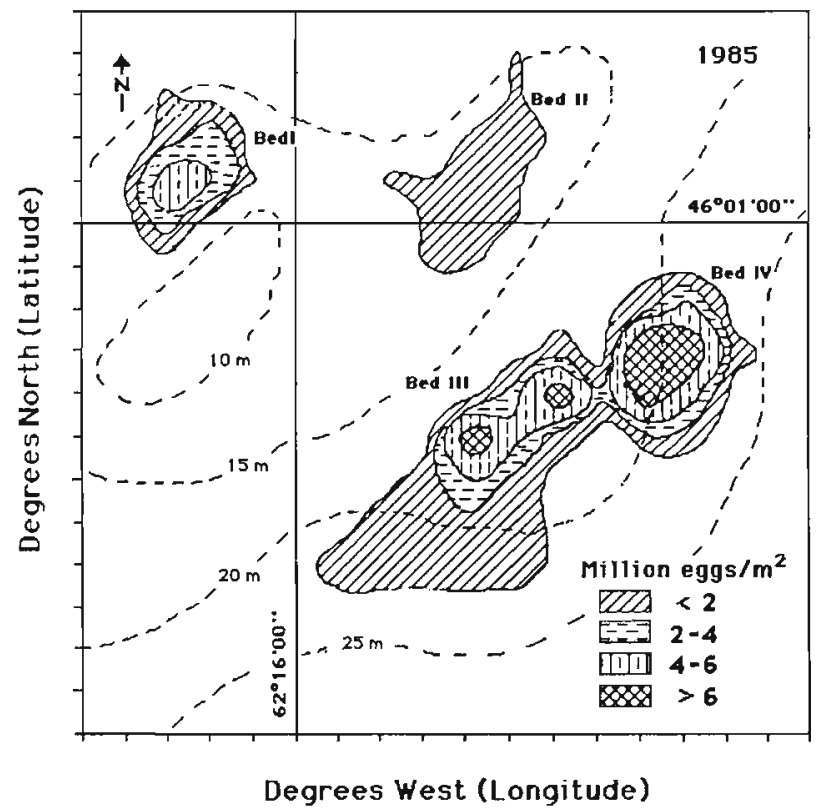

Figure 2. - Extension of herring spawning beds and density of egg deposition on Fisherman's Bank, Prince Edward Island, Canada during fall 1985.

The first spawning bed (fig. 2) was located at the west shoal of the Fisherman's Bank on September 6 . It occupied an area of approximately $286000 \mathrm{~m}^{2}$ (table 1). The intensity of egg deposition was heavy

Table 1. - Estimated area of herring spawning beds (based on diver observations), number of eggs per unit area and total number of deposited eggs on Fisherman's Bank, fall 1985.

\begin{tabular}{lccr}
\hline Spawning bed & $\begin{array}{c}\text { Area } \\
\left(\mathrm{m}^{2}\right)\end{array}$ & $\begin{array}{c}\text { Mean No. } \\
\text { of } \\
\text { eggs } \\
\left(\mathrm{m}^{2}\right)\end{array}$ & $\begin{array}{c}\text { Estimated } \\
\text { total egg } \\
\text { deposition }\end{array}$ \\
\hline I & 286000 & $2.59 \times 10^{6}$ & $7.41 \times 10^{11}$ \\
II & 488800 & $0.25 \times 10^{6}$ & $1.22 \times 10^{11}$ \\
III & 239000 & 4.710 & $0.0113 \times 10^{11}$ \\
IV & 247000 & $7.92 \times 10^{6}$ & $19.56 \times 10^{11}$ \\
V & 559500 & $2.82 \times 10^{6}$ & $15.78 \times 10^{11}$ \\
\hline
\end{tabular}


in most parts of the spawning bed, forming a thick mat ( 20 and 30 egg layers; about $4.5 \mathrm{~cm}$ thick) over an area of about $200 \times 500 \mathrm{~m}$. Most of the eggs on this spawning bed were in a state of deterioration, showing mass mortality in all layers and fungi over an extended surface area.

The 2 nd bed was located 3 days later (on September $9 ; 10$ to $15 \mathrm{~m}$ depth). The intensity of egg deposition was much less than on the 1st spawning bed and covered an area of $488800 \mathrm{~m}^{2}$.

The 3rd spawning bed was found on September 13 in about a $1 \mathrm{~km}$ distance southeast of the 2 nd spawning bed in a depth of about $20 \mathrm{~m}$ (area covered similar to 1 st bed). Spawning was very light as compared to all the others with eggs sporadically spread over the spawning bed.

The 4th spawning bed was found on September 18 . It was adjacent to the 3rd spawning site, in $20-35 \mathrm{~m}$ depth. The intensity of egg deposition on this spawning bed was highest.

\section{Observations on egg mass mortalities}

Samples of eggs where mass mortality was observed were almost solidly packed in a continuous mat, with very few cavities between eggs or egg layers. Egg mass reached thicknesses of up to 30 layers.

Most of the eggs were dead and were in various stages of deterioration. However, from microscopic observations along cross-sections of egg clusters it was obvious that the majority of the eggs (on average $95 \%$ had been fertilized and had reached some stage of development, mostly beyond the blastodisc stage. The near-bottom layers had obviously died at an early developing stage (probably late blastodisc, onset of epiboly) while most of the eggs in the three top layers contained advanced embryonic stages, which were close to the hatching stage.

\section{Microbiological examination of dead eggs}

A mixed growth of bacterial species was isolated from the egg mass, including Pseudomonas sp., Flavobacter sp. and marine Vibrio sp. No Myxobacteria were isolated. No viral agents which would cause cytopathogenic effects on the marine guppy cell line were detected. None of the isolates obtained are known to be specifically pathogenic for fish or fish eggs; they are considered to be opportunists commonly present in sea-water. Most egg samples appeared to be in an advanced stage of decomposition in the deeper layers. The opportunistic sea water bacteria obviously found the rich organics released from the deteriorating egg yolk material of the dead eggs to be a good substrate for growth.

There was no evidence of the presence of Ichthyophonus, the well-known fungus disease of herring, in any of the egg material examined. Although no fungi were isolated on Sabouraud's medium, histological and electronmicroscopic (EM) examinations indicated
Table 2. - Mean surface and bottom water temperatures $\left({ }^{\circ} \mathrm{C}\right)$ at Fisherman's Bank herring spawning grounds in September 1985.

\begin{tabular}{rcccc}
$\begin{array}{c}\text { Date } \\
\text { September }\end{array}$ & Water temperatures & $\begin{array}{c}\text { Egg } \\
\text { samples } \\
\text { surface }\end{array}$ & bottom & Remarks \\
\hline 5 & 19.5 & 17.0 & & \\
6 & 17.0 & 16.6 & $\times$ & Spawning bed I found \\
7 & 17.0 & 16.6 & $\times$ & \\
9 & - & 16.2 & $\times$ & Spawning bed II found \\
10 & 17.2 & 16.7 & $\times$ & \\
13 & 17.1 & 15.5 & $\times$ & Spawning bed III found \\
14 & & 15.5 & & \\
15 & 15.8 & 15.5 & & \\
16 & 16.0 & 15.9 & & \\
17 & 16.5 & 15.9 & & \\
18 & 16.5 & 16.0 & $\times$ & Spawning bed IV found \\
19 & - & - & & \\
23 & 17.8 & 16.0 & $\times$ & \\
24 & 17.0 & 15.5 & $\times$ & \\
25 & 16.7 & 15.6 & $\times$ & \\
26 & 15.8 & 15.2 & & \\
\hline
\end{tabular}

the presence of numerous bacteria and of at least two different species of fungus within the egg mass. Morphologically, however, they did not resemble the Ichthyophonus fungus. In spite of the presence of these fungi in histological sections, no fungi grew on Sabouraud's medium. A careful examination of EM sections did not reveal the presence of any viral particles.

\section{Hatching experiments with egg clusters}

Egg batches taken by divers were transferred to the laboratory within a few hours. Live embryos from the top layer continued to develop normally while those located in the second and third layers showed considerable retardation and various malformations. Those located in deeper layers were dying quickly, most of them within 48 hours after transfer. Incubated egg clusters had reached various stages of development at the time of transfer to the incubation tank.

The rate of development seemed to be related to the position within the egg mass. The number of layers in the total cluster was estimated to vary between 20 and 30 . Although most of the eggs (even within the inner region of the cluster) had at least partially gone through epiboly, all eggs below the second layer exhibited embryos with various forms of malformation. A very common one was unilateral or bilateral microphthalma (fig.4). Others included malformed lower jaws (also total lack of the lower jaw occurred), yolk deformations and various body curvatures. A large number of embryos showed extreme de-differentiations in various parts of the body and incomplete differentiation in the head (brain) region.

Most of the embryos from layers near the surface of the sample, except those from the top layer, hatched with serious body malformations. Only a few of these were observed to swim normally. Some embryos 


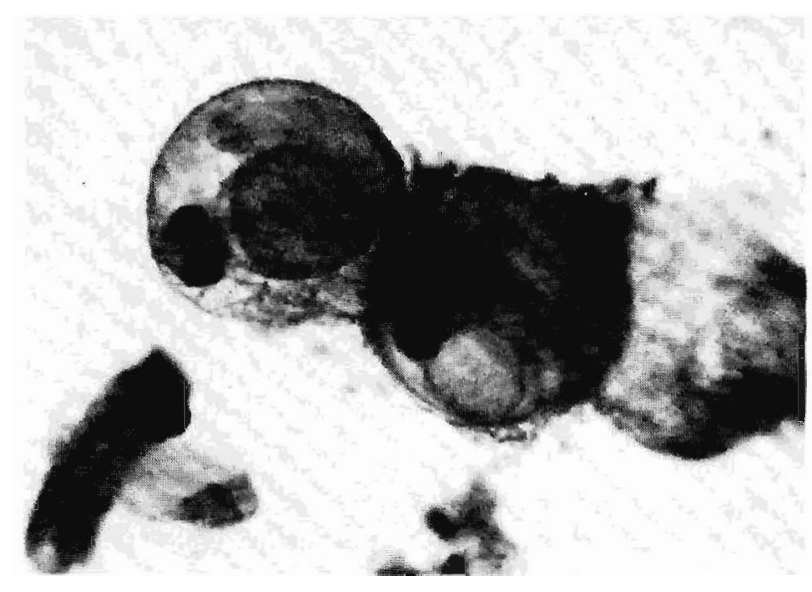

Figure 4. - Progressive retardation of herring egg development in densely packed egg patch. Eggs separated from three consecutive layers: top layer (right), an empty egg shell-larva hatched; second layer (middle), an advanced herring embryo, with few hatching glands and fully pigmented eyes; thrid layer (left), an embryo with bilateral microphtalmia and other malformation (non-viable).

(from deeper layers) which had reached an advanced stage of development showed occasional trembling movements. Almost all of the embryos from the top layer possessed numerous hatching glands, while those in the lower layers had developed fewer glands. Some of these embryos were ready to hatch but did not complete hatching because of the limited enzymatic digestion of the membrane.

\section{Temperature data}

Surface water temperature on the spawning grounds ranged between 15.0 and $19.5^{\circ} \mathrm{C}$ during the survey period (table 2). The day before the first spawning bed was found (September 5), the surface temperature was $19.5^{\circ} \mathrm{C}$. During the rest of the survey, the temperature ranged between $15.0^{\circ} \mathrm{C}$ low and $17.8^{\circ} \mathrm{C}$ high (average $16.7^{\circ} \mathrm{C}$ ).
Ryan's thermographs located near the spawning ground recorded temperatures continuously at $20 \mathrm{~m}$ depth during the first spawning period ( fig. 3). Temperature varied from 4.0 to $17.0^{\circ} \mathrm{C}$ during this period. On September 1 (D 244), temperature was $16.0^{\circ} \mathrm{C}$, and decreased steadily to $12.0^{\circ} \mathrm{C}$ on September 9 . During the spawning period large temperature fluctuations occurred repeatedly within a few hours. A very sharp increase in temperature occurred on September 10 , rising from 8.5 to $14.5^{\circ} \mathrm{C}$. Oscillations in the temperature regime of the spawning grounds continued until September 18 (D 261) with temperature variations ranging from 9.5 to $14.5^{\circ} \mathrm{C}$. Herring schools involved in the spawnings during that period must have experienced this rapid change and the eggs on these beds must have been exposed to several fluctuations. Thereafter the temperature became more stable, with an average of $14.5^{\circ} \mathrm{C}$ until the end of September.

\section{DISCUSSION}

The divers' observations that dead herring eggs over large areas of the spawning beds were covered with fungus led to the investigation of a possible relationship between fungal infection and mass mortality of eggs. However, the available information from results of the microscopic examination and the incubation trials indicate that fungal growth on the spawning beds was a secondary effect which followed the mass mortality and deterioration of several extended egg batches that had died from oxygen depletion.

The retarded development of embryos in the lower layers and the consequent mortality in bottom and middle layers appeared to be caused by a lack of oxygen, due to the dense packing of the egg layers allowing little separation for water and gas exchange. Similar effects have been observed on North Sea herring spawning beds and demonstrated in laboratory incubation trials (Hempel and Schubert, 1969;

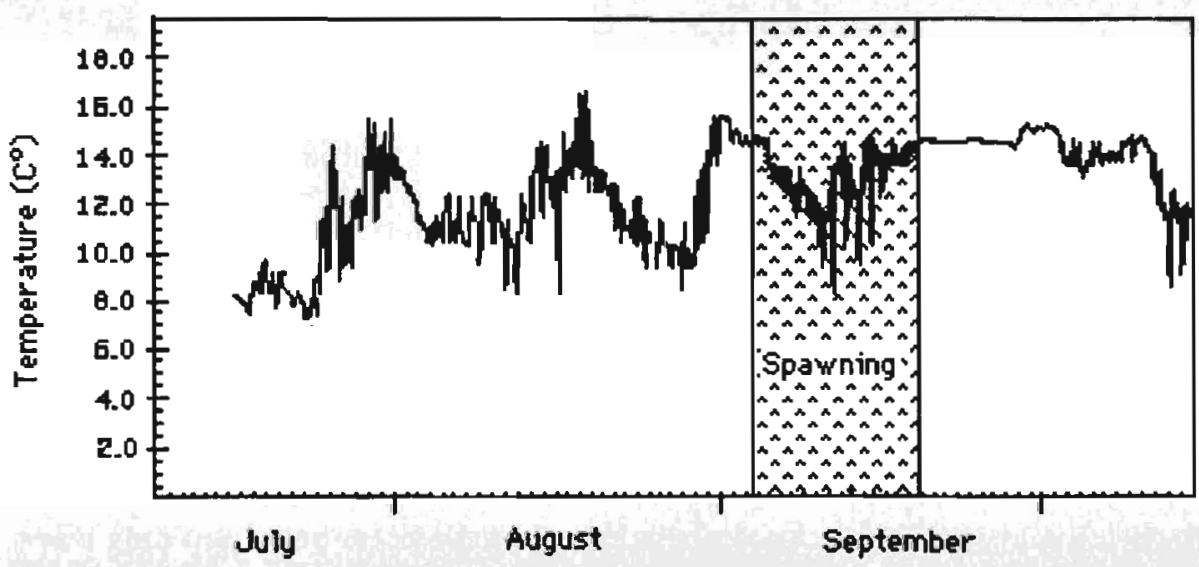

Figure 3. - Bottom temperatures near Fisherman's Bank herring spawning ground from mid-July to early October. 
Stelzer et al., 1971; Taylor, 1971; Braum, 1973; Hourston et al, 1981). Since herring eggs possess a relatively thick egg capsule characterized by a thin but solid central layer in addition to those that contain various types of pores (Odense and Rosenthal, 1986; Rosenthal and Odense, 1986), it is unlikely that any bacterial or fungal infection occurred inside the capsulc. There are no reports of fungi such as Ichthyophonus being transmitted to eggs from infected adults nor of it affecting ovaries in infected fish. This does not rule out the possibility that the adults were infected by Ichthyophonus. A bacterium known as Lactobacillus has been implicated in infections of fish ovaries but this organism was not isolated from these specimens.

The relatively thick herring egg capsule also requires a higher water velocity in the surrounding medium than that of other marine (pelagic) fish eggs, in order to ensure a reasonable gas diffusion capacity accross the membranc. Daykin (1965) applied the mass transfer theory of gases to fish egg survival and embryonic growth. He found that gas cxchange between media (internally and externally to the egg capsule) determine to a large extent the developmental rate, hatching time and embryonic growth (i.e. larval length at hatching, yolk size and condition factor).

The malformation of embryos observed in the rearing experiment indicates that energetic deficiencies had obviously occurred at a time prior to closure of blastopore when some of the differentiation patterns had not been initiated. Such metabolic deficiencies can be induced in herring embryos by a number of environmental stressors all affecting the energy budget. For example, the oxydative phosphorylation can be blocked prior to closure of blastopore by Dinitrophenol (DNP) (Stelzer et al., 1971) resulting initially in an arrest of the development, followed by substantial de-differentiations in various parts of the body (Rosenthal and Stelzer, 1970), with individual body cells migrating and dispersing over the cold syncytium. Instead of blocking the supply of ATP, the same effects can be initiated by a lack of oxygen during this period (Braum, 1972). Extreme salinities and other environmental stressors can cause similar effects (Alderdice and Velsen, 1971; Rosenthal and Sperling, 1974; Rosenthal and Alderdice, 1976; Hansen et al., 1985).

The question which should be addressed is how such a spontaneous mass spawning had occurred in the spawning beds over such extended areas $(500 \times 200 \mathrm{~m})$ resulting in this thickness and packing density, leaving little space between eggs. The fact that the density of egg deposition was unusual can best be demonstrated when compared with observations described from other areas. From Tibbo et al. (1963) calculations on total number of eggs deposited, it can be estimated that the overall density of eggs was at least two orders of magnitude lower than for most of the beds surveyed during the present study, although most of the eggs were deposited on vegetation. Hardwick (1973) reports egg densities for Pacific herring in Tomales Bay (near Bodego Bay, California) that ranged from 8000 per $\mathrm{m}^{2}$ to 1.2 million per $\mathrm{m}^{2}$, depending on substrate and vegetation. Similarly low egg densities were reported by Pottle et al. (1980), who described depositions in shallow waters $(0.9-$ $4.3 \mathrm{~m}$ depth), mainly on algae such as Chondrus crispus, Palmaria palmata, Fucus sp. and others. Egg density averaged 8500 per $\mathrm{m}^{2}$, with maxima occurring in clusters of up to 28400 eggs per $\mathrm{m}^{2}$.

The numbers of dead or unfertilized eggs in their samples were apparently negligible. Density of Pacific herring eggs spawned on vegetation seldom reaches the above reported values and are usually loosely packed due to the nature of the substrate (Hourston and Haegele, 1980; Hourston et al., 1981). High densities of Pacific herring eggs on the spawning grounds in British Columbia had been frequently observed (e.g. Hourston et al., 1972; Rosenthal and Alderdice, 1976).

Two possible causes of the spontaneous intensive spawn deposition have been considered. First, it is possible that herring spawning schools could have been disturbed by the fishing boats and drift nets near the spawning bed, resulting in "forced" spawning. Forced spawning was reported in earlier surveys in Miramichi Bay (Messieh et al., 1985a, b, 1987). However, this possibility was excluded due to the fact that the egg mat was evenly uniform over a wide area indicating natural deposition of eggs. The second possibility could relate the egg mass deposition and consequent mortalities to environmental factors. Previous years showed that herring spawning on Fisherman's Bank usually occurred between mid-August and mid-September. In 1985, the spawning time was about 2 weeks late. Based on the time of discovering the spawning beds, and taking into consideration the developmental stages of eggs, and an incubation period of approximately 9 to 10 days at temperatures of $15.5-16.5^{\circ} \mathrm{C}$, the spawning was estimated to have commenced on September 4 and ended on September 18. Meteorological data indicate that extended cool spring and summer periods prevailed in 1985. This may have prolonged the maturation period of herring resulting in delayed fall spawning.

Sub-surface temperature profiles near the spawning ground showed striking and abrupt changes in temperatures, coinciding with the spawning time. No dramatic changes in temperature near the surface were recorded at that time. This indicates that the observed changes in sub-surface temperature may be wind-related. According to Ekman's transport theory, a strong northwesterly wind tends to push the surface waters southward, away from the spawning ground. The reverse occurs during a southeasterly wind. Abrupt changes in temperature could last only a few hours, or up to a day or more. 
The sudden changes in bottom temperature may have caused the massive and excessive egg deposition, resulting in the observed egg mortalities. Abrupt changes in bottom temperatures are not unusual on the Magdalen Shallows where the Fisherman's Bank spawning beds occur. Observations were made in 1975 by Drinkwater (pers. comm.) in St. Georges Bay (a few kilometers southeast of the survey area), when a tropical storm passed through. Within a few hours, a change in temperature was observed of over $10^{\circ} \mathrm{C}$ at $30 \mathrm{~m}$.

The results of the Fisherman's Bank herring spawning survey emphasize the importance of the influence of environmental factors on the survival of herring eggs and their subsequent recruitment. It would be interesting to monitor the recruitment pattern of this stock, and to determine the factors involved in spawning patterns and reproduction success.

\section{Acknowledgements}

We wish to thank Dr. D. Scarratt for providing access to facilities at the Halifax Fisheries Research Laboratory. Mr. J. Cormick and Dr. M. Li of the same laboratory supervised the bacteriological studies. Dr. T. Sephton at the Fisheries Center University of PEI provided the aquarium facilities for egg incubation and participated in the study. Dr. K. Drinkwater of the Bedford Institute of Oceanography provided unpublished oceanographic data and advised in data analyses.

\section{REFERENCES}

Alderdice D., F. Velsen, 1971. Some effects of salinity and temperature on early development of Pacific herring (Clupea pallasi), J. Fish. Res. Board Can., 28, 1545-1562.

Braum E., 1973. Einflusse chronisation exogenen Sauerstoffmangels auf die embryogenese des Herrings (Clupea harengus). Neth. J. Sea Res., 7, 363-375.

Caddy J., D. lles, 1973. Underwater observations on herring spawning grounds on Georges Bank. ICNAF Res. Bull., 10, 131-139.

Daykin P., 1965. Application of mass transfer theory to the problem of respiration of fish eggs. J. Fish Res. Bourd Can., 22, 159-171.

Haegele C. W., A. S. H. Hourston, R. D. Humphreys, D. C. Miller, 1979. Eggs per unit area in British Columbia herring spawn depositions. Fish Mar. Serv. Tech. Rep., 894, 30 p.

Haegele C. W., R. D. Humphreys, A. S. Hourston, 1981. Distribution of eggs by depth and vegetation type in Pacific herring (Clupea harengus pallasi spawnings in British Columbia. Can. J. Fish. Aquat. Sci., 38, 381-386.

Hansen P. D., H. von Westernhagen, H. Rosenthal, 1985. Chlorinated hydrocarbons and hatching success in Baltic herring spring spawners. Mar. Environ. Res., 15, 59-76.

Hardwig J. E., 1973. Biomass estimates of spawning herring, Clupea harengus pallasi, herring eggs, and associated vegetation in Tomales Bay. Calif. Fish Game, 59, 36-61.

Hempel H., K. Schubert, 1969. Sterblichkeitsbestimmungen an einem Eiklümpen des Nordsee-Herings (Clupea harengus L.), Ber. dt. Wiss. Komm. Meeresforsch., 20, $79-$ 83.

Hourston A. S. H., H. Rosenthal, H. von Westernhagen, 1981. Condition at hatching of Pacific herring larvae from natural and artificial spawn of different intensities on a variety of substrates. Can. Tech. Rep. Fish. Aquat. Sci., 1045, $25 \mathrm{p}$.

Hourston A. S. H., C. W. Haegele, 1980. Herring on Canada's Pacific Coast. Can. Spec. Publ. Fish. Aquat. Sci, 48, $13 \mathrm{p}$.
Hourston A. S. H., D. N. Outram, F. W. Nash, 1972. Millions of eggs and miles of spawn in British Columbia herring spawnings 1951-1970 (Revised 1972). Fish. Res. Board Can. Tech. Rep., 359, 154 p.

Humphrys R. D., C. W. Haegele, 1976. An evaluation of herring spawn survey techniques used in British Columbia waters. Fish. Mar. Serv. Tech. Rep., 613, 142 p.

McKenzie R., 1964. Observations on herring spawning off southwest Nova Scotia. J. Fish. Res. Board Can., 21, 203-204.

Messieh S., 1988. Spawning of Atlantic herring in the Gulf of St. Lawrence. Am. Fish. Soc. Symp., 5, 31-48.

Messieh S., 1987. The effects of environmental conditions on the time of herring arrival on the spawning grounds in the Gulf of St. Lawrence. In: Environmental effects on recruitement to Canadian Atlantic Fish stocks. R. I. Perry, T. Frank ed. Can. Tech. Rep. Fish Aquat. Sci., 1556, 17-29.

Messieh S., R. Pottle, P. Macpherson, C. Bourque, $1985 a$. Herring spawning bed survey in Miramichi Bay, NB in spring 1984. Can. Atlant. Fish. Sci. Advis. Comm. Rea. Drc., 85/40, $18 \mathrm{p}$.

Messieh S., R. Pottle, P. Macpherson, T. Hurlbut, $1985 b$. Spawning and exploitation of Atlantic herring (Clupea harengus) at Escuminac in the southwestern Gulf of St. Lawrence, spring 1983. J. Northw. Atl. Fish. Sci., 6, 125133.

Noskov A., V. Zinkevich, 1967. Abundance and mortality of herring (Clupea harengus) on Georges Bank according to the results of egg calculation in spawning areas in 1964-1966. ICNAF Res. Doc., 67/98.

Odense P., H. Rosenthal, 1986. Surface structure of the herring egg capsule. Proc. Microscop. Soc. Canada, 13, 76-77.

Pottle R. A., P. A. Macpherson, S. N. Messieh, D. S. Moore, 1980. A SCUBA survey of a herring (Clupea harengus L.) spawning bed in Miramachi Bay, NB, Can. Tech. Rep. Fish. Aquat. Sci., 984, 1-13. 
Rosenthal H., D. Alderdice, 1976. Sublethal effects of environmental stressors, natural and pollutional, on marine fish eggs and larval. J. Fish. Res. Board Can., 33, 20.47-2055.

Rosenthal H., P. Odense, 1986. Fertilization in herring egzss: scanning electron microscopic study. ICES/CM, $1935 / \mathrm{H}, 40$ (mimeo).

Rosenthal H., V. Sperling, 1974. Effects of cadmium on development and survival of herring eggs, p. 383-395. In: The Early Life History of Fish, J. Baxter ed., Springer, Earlin

Schweigert J. F., D. Fournier, 1982. A model for predicting Pacific herring (Clupea harengus pallasi) spawn density from diver observations. Can. J. Fish. Aquat. Sci., 39 , 1351-1355.

Stelzer R., H. Rosenthal, D. Siebers, 1971. Einfluss von 2,4-dinitrophen 1 auf die Atmung und die konzentration einiger Metabolite bei Embryonen des Herings Clupea harengus. Mar. Eiol., 11, 3ธ์-378.

Taylor F. H. C., 1971. Variation in hatching succoss in Pacific herring (Clupea pallasii) eqgoss with water depth, temperature, salinity and eza mass thickness. Rapp. $P$. v. Réun. Cons. int. Explor. Mer, 103, 30-33.

Tibbo S. N., D. J. Scarratt, P. W. G. Mclilulion, 1553. An investigation of herring (Clapea harergus L.) spawring using free-diving techniques. J. Fish. Res. Loard Can., 20, 1C57-1079. 